DOI : $10.14746 /$ rie.2015.9.38

\title{
Joseph Ratzinger, Europa Benedykta w kryzysie kultur, Wydaw- nictwo Edycja Św. Pawła, Częstochowa 2005, ss. 141.
}

Integracja europejska jest dobrowolnym procesem łączącym państwa kontynentu europejskiego wokół katalogu wartości sformułowanych w kolejnych traktatach podstawowych Unii Europejskiej. Szukając fundamentów integracji europejskiej można wskazać na wiele elementów identyfikacji wartości wspierających konstrukcję unijną. Dla państw wyrażających chęć przystąpienia do Unii, katalog warunków akcesyjnych określają przepisy Traktatu o Unii Europejskiej. Są one podstawą do oceny wniosku akcesyjnego i wskazują obszary negocjacji akcesyjnych prowadzonych przez Komisję Europejską.

Dyskusja o wartościach, na których ma być oparta Unia Europejska, nie jest nowym forum debaty o europejskiej tożsamości. Dość wspomnieć o pracach licznych gremiów, które zajmowały się tą tematyką przy okazji pracy nad treścią Karty Praw Podstawowych UE czy też prac nad treścią Traktatu Ustanawiającego Konstytucję dla Europy (dalej TKE). Pytania o tożsamość europejską pojawiają się prawie zawsze w momentach przełomowych dla Unii Europejskiej. Są one często określane mianem kryzysu integracji. Ostatni kryzys traktatowy związany z nieprzyjęciem Traktatu Ustanawiającego Konstytucję dla Europy, czy też aktualny kryzys imigracyjny pośrednio dotykają spraw określających filozofię, na której założeniach ma być budowana przyszła Unia Europejska.

W opublikowanej w przededniu swego wyboru na Stolicę Apostolską książce, Joseph kard. Ratzinger kreśli główne wą̨ki refleksji na temat tożsamości europejskiej. Okazją do przedstawienia swego punktu widzenia na ten temat była kończąca się debata o kształcie tzw. konstytucji europejskiej, a w szczególności o umieszczeniu w jej preambule invocatio Dei. W tym miejscu warto przypomnieć o propozycji invocatio Dei, którą polska delegacja na Konwent Europejski próbowała przedstawić jako tę łączącą różne postawy wokół wspólnych wartości wywodzących się z różnych obrządków religii monoteistycznych.

We wstępie do rozważań przyszły papież diagnozuje współezesne problemy Europy. Warto zauważyć, że argumentacja przytoczona przez kard. Ratzingera jest znaną już chociażby z licznych stanowisk Rady Konferencji Biskupów Europy, nauczania poprzednich papieży czy też brzmi w ostatnim przemówieniu papieża Franciszka podczas Jego wizyty w siedzibie Parlamentu Europejskiego w Strasburgu. Diagnoza kard Ratzingera sięga jednak głębiej niż prosta analiza licznych programów integracyjnych czy też antykryzysowych. Ratzinger ukazuje problemy Europy, które w jego przekonaniu są skutkiem uprzedmiotowienia człowieka w filozofii pozytywistycznej. Przyszły papież jasno daje do zrozumienia, że kryzysowi integracji towarzyszy kryzys kultur. Nowa Europa odwołująca się do filozofii oświecenia staje się punktem wyjścia racjonalizmu naukowego, który wykluczając Boga jako praprzyczynę wszystkiego promuje techniczną mentalność zawężającą moralność do sfery subiektywnej. Przechodząca „próbę swego napędu" (s. 48) Europa promuje człowieka jako produkt naszego działania. Jednak wzrostowi naszych możliwości nie odpowiada równoczesny rozwój naszej moralnej siły - pisze Ratzinger (s. 43). Stąd problemem dzisiejszej ludzkości jest brak równowagi między technicznymi możliwościami a siłą moralną. Buduje się świat (w domyśle Europę) (s. 46) supremacji człowieka, który jednak oparty na kalkulacji relatywizuje dobro, które w konsekwencji traci swe pierwotne znaczenie. Staje się to również w systemach politycznych, które ze swej natury powinny stać na straży niezbywalnych praw jednostek. Zamieniają się one jednak w systemy, które jako przeliczniki głosów nie zastępują mądrości (s. 35). Przyszły papież stawia tezę, że ,w dyskusji na temat definicji Europy i jej nowej formy politycznej nie chodzi tyle o jaką́s nostalgiczną bitwę «tylnej straży», co raczej o wielką odpowiedzialność za współczesną ludzkość" (s. 48). W toku wywodu 
uznaje za niedorzeczną argumentację przeciwników umieszczenia w TKE invocatio Dei i oparcia podstaw Unii na prawach filozofii uniwersalnej. Zadaje pytanie: kogo miałoby obrażać invocatio Dei? Zarówno wyznawcy judaizmu, chrześcijanie, jak i muzułmanie - wskazuje kard. Ratzinger - korzeniami swoich religii dotykają góry Synaj, i tym samym nie zwrot deistyczny, lecz usiłowanie zbudowania ludzkiej wspólnoty całkowicie bez Boga, jest odbierane jako promocja antymetafizycznej filozofii pozytywistycznej i związanej z nią powszechnej laicyzacji. Autor dokonuje przeglądu dzieł E. Kanta, B. Pascala, którzy przedmiotem swych rozważań czynili relację między wiara, rozumem, prawem boskim, ziemskim. Wyprowadza z tego katolicką definicję tolerancji streszczoną w słowach veluti si Deus daretur - odwrócenie aksjomatu oświecenia przyjmujące za punkt wyjścia uznanie, że w niczym nieograniczającym wolność, a dającym oparcie i kryterium identyfikacji jest działanie tak jakby Bóg istniał (s. 70). W dalszych częściach wywodu, kard. Ratzinger kreśli obraz człowieka wierzącego, zaangażowanego w życie społeczne. Stawia ponownie pytanie o to, czy agnostycyzm może być rozwiązaniem wszystkich wątpliwości człowieka? W jakich relacjach pozostają wiara i rozum? Jak definiować naturalne poznanie Boga i jakie z tego wypływają konsekwencje dnia codziennego?

Rozwinięcie powyższych wątków stanowią poglądy kard. Ratzingera głoszone już po wyborze na urząd papieża. W udzielonym P. Seewaldowi wywiadzie zatytułowanym, Światłość Swiata" (Wydawnictwo Znak, Kraków 2011), Benedykt XVI mówi o wygaszaniu obrazu Boga, które służy kulturze relatywizmu. Jako przyczynę kryzysu gospodarczego i politycznego wskazuje na brak etyki i współodpowiedzialności za losy przyszłych pokoleń. Postęp dzisiejszych czasów, zdaniem Benedykta XVI, jest niszczycielski. Dlatego też przy opracowaniu kryteriów postępu należy zwrócić szczególną uwagę na ponowne zdefiniowanie koncepcji osoby ludzkiej. Sojusz postępu, wiedzy i władzy wymaga wplecenia pojęcia dobra, postawienia fundamentalnych pytań o to jaka wiedza jest wiedzą dobrą dokąd wiedza ma prowadzić władzę? (s. 54 i 55). Konieczność wypracowania równowagi ma przezwyciężyć kulturę relatywizmu. Nie tylko w tym kontekście koncepcja Europy Josepha kard. Ratzingera jest spójna z ostatnią Encykliką papieską Laudato Si! - Franciszka. Obecny papież przestrzega przed dramatem polityki skoncentrowanej na doraźnych rezultatach, wspieranej przez konsumpeyjną ludność. Przed polityką rodzącą krótkoterminowy rozwój (s. 112). Dostrzegany również przez tego duchownego dychotomiczny podział między państwa bogate i państwa biedne, na zwycięzców i pokonanych, wymaga określenia kryteriów odpowiedzialności gwarantującej zrównoważony [etyczny - przyp. M.T.] rozwój ludzkości.

Europa Benedykta w kryzysie kultur autorstwa Josepha kard. Ratzingera to ważny, nie nowy, ale mało znany głos w dyskusji o kondycji ludzkości. Tłem, przyczyną podjętej refleksji jest toczona na przełomie 2003 i 2004 roku debata na temat invocatio Dei w nowym traktacie Unii Europejskiej. Pytanie o tożsamość europejską, o powody zagrożenia terrorystycznego, o zasady współistnienia na kontynencie europejskim wyznawców wielu religii, w kontekście rezygnacji przez Unię z założeń polityki wielokulturowości, staje się nad wyraz aktualne. Książka liczy 141 stron. Została poprzedzona wstępem napisanym przez o. Leona Knabita (wstęp do wydania polskiego) oraz przez Marcello Pera. Książka stanowi rozwinięcie wykładu autora, który został wygłoszony w Subiaco. Podział na trzy części z rozwinięciem treści w podpunktach dodatkowo zatytułowanych, porządkuje niełatwy wywód.

Ze względu na aktualności prezentowanych tez, jak również obecną sytuację, w której znajduje się Europa, książka ta może być przedmiotem seminarium naukowego nie tylko studentów filozofii, teologii, ale również nauk o polityce. Interesujące jest badanie wspólnych wątków nauczania papieskiego w ostatnich latach. Wydaje się, że dla lepszego zrozumienia tez encykliki Laudato Si!, należy przestudiować myśli kard. Ratzingera, późniejszego Benedykta XVI.

MIKOLAJ TOMASZYK

Uniwersytet im. Adama Mickiewicza w Poznaniu 